\title{
NILAI KERJA DITINJAU DARI ETNIS BATAK TOBA PADA ANGGOTA SATUAN BRIGADE MOBILE KEPOLISIAN DAERAH SUMATERA UTARA
}

\author{
Debi Angelina Br. Barus \\ Email: debibarusok@gmail.com
}

Fakultas Ilmu Sosial, Program Studi Psikologi Universitas Nusa Nipa Maumere

\begin{abstract}
This study aims to determine the relationship of work values with the Batak Toba ethnic. This research was conducted at the Mobile Brigade Unit of the North Sumatra Regional Police. The subjects in this study were 45 people. This study uses a quantitative description approach. The results of the study are to find that hamoraon, hagabeon and hasangapon $(3 \mathrm{H})$ are in line with the principle of the work value of Brimob members. $3 \mathrm{H}$ is the peak achievement of individual Toba Batak ethnic work value in the mobile brigade unit of the North Sumatra regional police.
\end{abstract}

Keyword: Work value, Batak Toba Etnic

Abstrak. Penelitian ini bertujuan untuk mengetahui hubungan nilai kerja dengan etnis Batak Toba.
Penelitian ini dilakukan di Satuan Brigade Mobile Kepolisian Daerah Sumatera Utara. Subjek dalam
penelitian ini adalah 45 orang. Penelitian ini menggunakan pendekatan kuantitatif deskripsi. Hasil
penelitian adalah menemukan bahwa hamoraon, hagabeon dan hasangapon (3H) sejalan dengan prinsip
nilai kerja pada satuan anggota Brimob. $3 \mathrm{H}$ merupakan puncak pencapaian dari nilai kerja individu yang
beretnis Batak Toba di satuan brigade mobile kepolisian daerah Sumatera Utara.

Kata Kunci: Nilai kerja, Etnis Batak Toba

8 | Psychophedia Jurnal Psikologi Universitas Buana Perjuangan Karawang 


\section{Pengantar}

Brigade Mobile kepolisian daerah Sumatera Utara merupakan oraganisasi satuan elit militer yang dimiliki oleh negara Indonesia. Sebagai organisasi militer Indonesia, Brimob memiliki visi, misi dan aturan tersendiri yang telah disepakati bersama secara internal dalam organisasi Brimob. Fungsi dari nilai kerja tersebut untuk mengatur sikap dan perilaku anggota Satuan Brimob dalam bekerja. Adapun nilai kerja organisasi Satuan Brimob adalah bekerja dengan disiplin, penuh tanggung jawab, jujur, mengutamakan keamanan masyarakat, memberikan pelayanan yang terbaik bagi masyarakat. Nilai kerja tersebut merupakan sebagai pedoman bagi anggota dalam bekerja namun mengingat jumlah anggota Satuan Brimob yang begitu banyak dan beragam maka sangat penting sekali nilai kerja diterapkan secara konsisten agar semua anggota diharapkan dapat bekerja secara professional sehingga apa yang menjadi tujuan atau visi dan misi satuan Brimob tercapai.

Salah satu yang menjadi nilai kerja Satuan Brimob adalah bekerja merupakan pengabdian dan memberikan pelayanan yang terbaik kepada masyarakat yang mencakup dengan aspek keamanan. Dari nilai kerja yang ditanamkan kepada semua anggota Satuan Brimob diharapan semua anggota dapat mengamalkan nilai tersebut dalam bersikap dan berperilaku ketika menjalankan tugas atau pekerjaanya. Ketika semua anggota dapat bekerja sesuai dengan nilai kerja yang ditanamkan oleh Satuan Brimob maka tujuan dari organisasi tercapai dan image Brimob dimasyarakat menjadi positif.

Pada kenyataanya tidak semua anggota Satuan Brimob bekerja sesuai dengan nilai kerja yang diterapkan, hal ini disebabkan karena setiap anggota memiliki nilai tersendiri yang sudah dibawa dari pola pengasuhan atau budaya yang membesarkanya. Sehingga tidak semua anggota memiliki nilai kerja yang sama walaupun berada dalam satu instansi. Nilai yang dibawa sejak dulu karena faktor budaya, akan melekat dalam diri individu sehingga menjadi sebuah keyakinan, pandangan hidup yang menggerakkan individu dalam mecapai tujuan, berperilaku terhadap pekerjaan yang dilakukan.

Hofstede (dalam Matsumoto \& Juang, 2000) nilai kerja (work value) merupakan orientasi individual dan sikap terhadap pekerjaannya sendiri, terhadap hubungan personalnya dengan anggota perusahaan dan loyalitas kepada perusahaan maupun organisasi. Nilai kerja sangat berkaitan dengan sikap, persepsi dan kepercayaan individu terhadap pekerjaannya. Sheilla (2013) nilai kerja juga boleh dijadikan petunjuk untuk menilai sejauh mana penilaian pekerja terhadap kerjanya dan bagaimana pula kebanggaan, rasa tanggung jawab, kesungguhan, cara bekerja dan akhirnya, prestasi kerja yang dihasilkan.

Chu (2007) berpendapat bahwa nilainilai pemahaman karyawan adalah sangat penting karena sejauh mana karyawan menghargai pekerjaan mereka, mempengaruhi sikap mereka terhadap pekerjaan. Beberapa studi melaporkan bahwa nilai cenderung memiliki pengaruh yang signifikan atas berbagai sikap dan perilaku. Nilai kerja yang dianut oleh seseorang tidak lepas dari pengaruh budaya setempat yang berlaku di masyarakat.

Penilitian yang dilakukan Sheilla (2013) menyatakan bahwa nilai kerja yang dianut oleh suku Jawa adalah disiplin, loyalitas dan jujur, sedangkan nilai kerja yang dipengang oleh suku Batak belum tentu sama dengan suku Jawa. Dengan perbedaan tersebut maka otomatis perilaku yang tampak dalam bekerja juga pasti berbeda-beda antara anggota yang satu dengan anggota yang lain.

Hasil wawancara yang dilakukan terhadap bidang SDM menyatakan bahwa anggota yang beretnis Batak Toba jika diperintahkan terhadap tugas sangat siaga dan cekatan namun emosional kurang stabil, loyalitasnya terhadap pimpinan kurang, sementara anggota yang beretnis Jawa memiliki loyalitas kepada pimpinan dan lebih tenang dalam bertindak. Selain itu ditemukan juga bahwa anggota etnis Batak memiliki ambisi yang tinggi untuk terus mengembangkan diri, terutama rata-rata mereka memiliki dorongan untuk meningkatkan pengetahuan salah satunya dengan melanjutkan pendidikan yang lebih tinggi. 
Pada kasus yang lain, anggota yang beretnis Batak Toba memiliki harga diri yang tinggi sehingga sering muncul sifat arogansi dalam memberikan pelayanan terhadap masyarakat. Sekitar lima kasus pelaporan ke kantor tentang perilaku anggota yang beretnis Batak Toba yang kurang mengayomi masyarakat dan kurang memberikan pelayanan yang terbaik. Sikap tersebut tidak lepas dari nilai etnis Batak Toba yang mengatakan "anak ni Raja (anak Raja)" nilai tersebut ditanamkan sehingga menjadi sebuah keyakinan, hal tersebut yang menyebabkan masyarakat Batak jarang bekerja di bawah kendali atau perintah, karena sudah memposisikan sebagai anak raja yang selalu dilayani bukan untuk menjadi pelayan.

Masyarakat Batak memiliki prinsip hidup dengan konsep $3 \mathrm{H}$ yaitu hagabeon (keturunan), hamoraon (kekayaan) dan hasangapon (kehormatan). Ketidakberhasilan individu dari etnis Batak dalam mewujudkan konsep $3 \mathrm{H}$ tersebut dianggap sebagai ketidaksempurnaan dalam hidupnya terutama dihadapkan pada suatu acara adat (Sitompul, 1991). Etnis Batak memiliki motto hidup "Anakhonhi do hamoraon di ahu" yang artinya adalah "anak merupakan harta bagi orang tua". Nilai ini yang mendorong Batak Toba identik sebagai pekerja keras, yang diperkuat dengan budaya 3H: Hamoraan, Hagabeon, Hasangapon (Sagala, 2014). Demi kekayaan, status sosial mereka dipacu menjadi sedikit ambisius dari subetnis lainnya.

Etnis sangat berperan penting dalam menentukan sesorang berperilaku dalam bekerja, sehingga penting sekali suatu organisasi atau perusahan mengetahui lebih awal tentang nilai kerja yang dimiliki oleh anggota pada tahap seleksi, agar anggota dapat bekerja secara profesional sesuai harapan organisasi.

Nilai kerja yang didapat dari pengaruh budaya merupakan hal yang menarik untuk saat ini diteliti. Sebelumnya terdapat penelitian kajian etnis Jawa (Sheila, 2013) yang meneliti tentang nilai kerja pegawai etnis Jawa, dimana dalam penelitian tersebut menyatakan bahwa nilai kerja yang diyakini oleh pegawai etnis Jawa adalah disiplin, jujur dan loyalitas. Selain itu terdapat juga penelitian Jayanti (2015) tentang nilai kerja TNI-AD berdasarkan jenjang usia dan Karir.
Hasil penelitian tersebut menunjukan bahwa anggota yang berusia 30 tahun memiliki nilai kerja kenyamanan, usia 31-40 memiliki nilai kerja altruisme, usia 45 tahun memiliki nilai kerja status dan yang terahkir diusia 55 tahun memiliki nilai kerja prestasi. Namun hal yang menarik dalam penelitian ini adalah bahwa etnis Batak Toba merupakan salah satu etnis di Indonesia yang kuat memegang teguh nilai-nilai budaya sedangkan organisasi satuan brigade mobile kepolisian daerah Sumatera Utara juga memiliki nilai kerja yang semua anggota wajib meyakininya, perpaduan nilai budaya Batak Toba dan organisasi satuan brigade mobile kepolisian daerah Sumatera Utara yang sama-sama dominan merupakan hal yang menarik dan baru untuk diteliti.

Connor and Becker (dalam Sheila, 2013) menyatakan bahwa tingkah laku pada umumnya merupakan manifestasi nilai dan sikap. Hal ini juga sesuai dengan salah satu isu yang akhir-akhir ini mendominasi literatur manajemen sumber daya manusia yang memfokuskan pada nilai-nilai dan norma. Nilai-nilai kerja individu itu penting karena nilai merupakan pondasi untuk memahami sikap dan motivasi di dalam bekerja pada suatu organisasi. Walker (1992) menyatakan bahwa individu, lingkungan organisasi dan lingkungan sosial mempengaruhi perilaku dan kinerja secara keseluruhan. Salah satu penunjang pematangan karir seseorang ialah nilai pekerjaan mereka. Itulah sebabnya tidak mengherankan bahwa minat terhadap nilai kerja telah menerima banyak perhatian selama beberapa dekade karena pentingnya dalam menentukan perilaku karyawan.

\section{Landasan Teori}

Nilai Kerja (work value)

Hofstede (dalam Matsumoto dan Juang, 2000) mengemukakan nilai kerja adalah orientasi individual dan sikap terhadap pekerjaannya sendiri, terhadap hubungan personalnya dengan anggota perusahaan dan loyalitas kepada perusahaan maupun organisasi. Arenawati (2010) berpendapat bahwa nilai kerja adalah nilai-nilai dasar yang kemudian membentuk nilai-nilai luhur dalam bekerja, yang menjadi modal dasar seseorang untuk melangkah lebih jauh dalam pengembangan karirnya di kemudian hari. 
Jayanti (2015) nilai kerja adalah keyakinan individu terkait dengan prestasi dalam bekerja. Menurut Robbins (2005) nilai kerja merupakan fondasi untuk mengerti sikap dan motivasi yang dapat mempengaruhi persepsi individu sehingga nilai kerja sangat penting untuk dimiliki oleh individu. Persepsi tersebut berhubungan dengan kebutuhan hidup dari individu, apabila kebutuhan hidup individu terpenuhi maka individu akan merasa puas dan kepuasan tersebut akan memicu untuk mendapatkan nilai kerja yang diinginkan oleh individu. Sheila (2013) menyatakan nilai kerja merupakan salah satu penentu keberhasilan suatu organisasi karena kecemerlangan sebuah organisasi sangat bergantung pada nilai kerja individu. Nilai kerja merujuk pada sikap individu terhadap kerja dan berkaitan dengan makna yang diberikan oleh individu terhadap kerja. Nilai kerja penting karena mempengaruhi perilaku organisasional, performa kerja, produktivitas dan komitmen organisasi.

Aspek-aspek nilai kerja Wollack (dalam Sheilla, 2013) adalah kehormatan, disiplin, tanggung jawab, keluarga, kejujuran, kerja keras, ikhlas. Aspek-aspek work value menurut Tevruz dan Turgut (dalam Uçanok, 2008) adalah sebagai berikut: 1). Aspek Individualistis, meliputi mencari informasi, kebebasan, menyibukkan diri, mencari tindakan, dan mencari hal yang berarti dalam kehidupan pribadi. 2). Aspek Nilai-nilai Normatif, meliputi pemenuhan kewajiban agama, membantu masyarakat, menciptakan ketertiban, dan menghindari hal-hal yang negatif seperti menghindari keterasingan dan berjuang untuk selalu berada di jalur yang benar. 3). Aspek Duniawi, meliputi kenikmatan dan status pencapaian terhadap sesuatu yang diinginkan dan dibutuhkan.

Anoraga (2006) faktor-faktor yang mempengaruhi nilai kerja yaitu: 1). Faktor Internal, merupakan faktor yang berasal dari dalam individu, yang terdiri dari: a). Kebutuhan Fisiologis Dasar, merupakan kebutuhan fisik dan biologis, misal makan, minum, tempat tinggal dan lain-lain. Kebutuhan ini merupakan kebutuhan untuk mendapatkan penghidupan yang layak. b). Kebutuhan Sosial, merupakan kebutuhan untuk mendapatkan afeksi atau bergaul dan manusia tidak akan bahagia apabila ditinggalkan sendirian dalam jangka waktu yang lama. Sejatinya manusia merupakan makhluk sosial, tidak bisa hidup sendiri, selalu membutuhkan orang lain. c). Kebutuhan Egoistik, lebih mengarah kekebutuhan psikologis, dimana kebutuhan tersebut dapat memberikan suatu kepuasan dan menjadi konsep dasar seseorang bekerja. 2). Faktor Eksternal, merupakan faktor yang berasal dari luar individu yaitu: a). Etnis, yaitu pengalaman yaitu nilai didasari pada pengalaman-pengalaman yang dikembangkan dari hampir seluruh peristiwa sejak lahir. b).Orang lain yaitu orang yang paling berpengaruh pada individu adalah orang tuanya. Dalam penelitian ini, faktor-faktor yang mempengaruhi nilai kerja adalah etnis.

Etnis Batak Toba

Masyarakat Batak adalah salah satu bangsa yang berasal dari Sumatera Utara yang bermukim di wilayah mulai dari daerah Langkat, Deli Serdang, Asahan, dan bagian pegunungan dataran tinggi Karo, daerah sekitar Pematang Siantar, daerah Danau Toba, dan hampir seluruh daerah di Tapanuli hingga daerah Natal serta perbatasan Sumatera Barat. Suku Bangsa Batak mempunyai lima sub suku dan masing-masing wilayah utama, sekalipun sebenarnya wilayah itu tidak sedominan batas-batas pada zaman lalu. Sub suku Batak yang dimaksud yaitu: Batak Karo, Batak Simalungun, Batak Pak-pak, Batak Toba, Batak Angkola Mandailing. Dari kelima Sub suku tersebut bisa dikatakan Batak Toba paling banyak jumlahnya dan paling banyak merantau keluar daerah Tapanuli jika dibandingkan dengan sub suku lainnya (Sitanggang, 1996).

Nilai inti dari suatu budaya bangsa atau suku bangsa biasanya mencerminkan jati diri suku atau bangsa yang bersangkutan. Sedangkan jati diri itu maksudnya merupakan gambaran atau keadaan khusus seseorang yang meliputi jiwa atau semangat daya gerak spiritual dari dalam. Dari pengertian itu dapat dipahami bahwa nilai inti budaya Batak cukup luas. Ada delapan nilai inti budaya Batak (Sitanggang, 1996), yaitu: 1). Kekerabatan, 2). Agama, 3). Hagabeon (Kesuburan, banyak keturunan), 4). Kekayaan 
(Hamoraon), 5). Kehormatan (Hasangapon), 6). Hukum adat dan kebudayaan (Uhum dan Ugari), 7). Perlindungan (Pengayoman), 8). Saling mengerti (Marsisarian). Aspek-aspek Adat budaya Batak Toba menurut Sinaga (2000) yaitu Kehormatan, Kekayaan, Kesuburan. Aspekaspek ini akan dijadikan sebagai alat ukur dalam penelitian ini.

\section{Metode Penelitian}

Pendekatan penelitian ini adalah menggunakan pendekatan kuantitatif. Sugiyono (2014) mengemukakan bahwa penelitian kuantitatif menggunakan instrumen-instrumen formal, standar dan bersifat mengukur. Sementara penelitian kualitatif menggunakan peneliti sebagai instrumen. Subjek penelitian adalah anggota satuan brigade mobile kepolisian daerah Sumatera Utara, yang beralamat di Jl. Wahid Hasyim No. 3i Medan. Penelitian ini menggunakan teknik snowball sampling, di mana peneliti akan menghubungi beberapa partisipan yang memenuhi kriteria (qualified volunteer sample) dan kemudian meminta partisipan yang bersangkutan untuk merekomendasikan teman, yang memenuhi kriteria untuk dijadikan sebagai partisipan penelitian (Morissan, 2012). Sampel dalam penelitian ini adalah 45 orang. Teknik pengumpulan data menggunakan skala nilai kerja dan skala etnis budaya Batak Toba.

\section{Hasil Dan Diskusi}

Nilai Kerja Ditinjau dari Etnis Batak Toba.

Sikap individu dalam bekerja tidak lepas dari pengaruh nilai-nilai budaya menanakan sebuah keyakinan, pandangan hidup kepada masyarakat. Etnis Batak Toba merupakan salah satu etnis yang ada diindonesia yang memiliki nilai kebudayaan yang kental yang terus diturunkan kepada generasi. Etnis Batak terkenal dangan karakter yang keras, berani, berprinsip kuat dan spontanitas, maka tidak heran etnis Batak Toba paling banyak survive diperantauan. Tujuan hidup Etni Batak Toba dikenal dengan $3 \mathrm{H}$, yaitu hagabeon, hamoraon dan hasangapon, dimana konsep 3H merupakan visi dan tujuan hidup etnis batak toba (Sibarani, 2013)
Dari hasil penelitian menunjukan bahwa anggota satuan Brimob yang beretnis Batak Toba memiliki nilai kerja kehormatan (hasangapon) sebanyak 19 orang, dimana kehormatan bagi masyarakat Batak Toba merupakan falsafah atau pedoman hidup etnis Batak Toba. Nilai kerja dalam pencapaian Kekayaan (hamoraon) sebanyak 16 orang. Kekayaan merupakan aspek lain dari nilai budaya Batak Toba yang menjadi dasar dan dorongan mencari kekayaan sebanyak mungkin (Tambunan, 2015). Hasil penelitian inipun didukung oleh penelitain (Simarmarta, 2017) yang mengungkapkan masyarakat Batak Toba terpancu untuk mengumpulkan kekayaan sebanyak-banyaknya, sehingga tidak heran dalam bekerja orang Batak Toba terkenal dengan pekerja keras, memiliki semangat juang yang tinggi, perilaku tersebut tidak lepas dari falsafah dan tujuan hidupnya untuk mencapai kekayaan. Aspek nilai kerja terakhir adalah kesuburan/memiliki banyak keturunan (hagabeeon) sebanyak 10 orang. Hagabeon adalah aspek puncak bagi masyarakat Batak Toba. Kekayaan dan kehormatan tidak berarti ketika individu tidak memiliki keturunan. Ketiga aspek ini menjadi nilai penting bagi masyarakat Batak Toba dalam bekerja. Berikut tabel nilai budaya etnis Batak Toba.

Tabel 1 Nilai Budaya Etnis Batak Toba

\section{No Nilai Etnis Frekuensi Persen Batak Toba}

\begin{tabular}{cccc}
\hline $\mathbf{1}$ & Hasangapon & 19 & 42.2 \\
\hline $\mathbf{2}$ & Hamoraon & 16 & 35.6 \\
\hline $\mathbf{3}$ & Hagabeon & 10 & 22.2 \\
\hline \multirow{2}{*}{ Jumlah } & 45 & $100 \%$ \\
\hline
\end{tabular}

Nilai hasangapon, hamoraon dan hagabeon tidak bisa berdiri sendiri dan tidak bisa dipisahkan satu sama lain, karena ketiga nilai tersebut saling berkaitan satu sama lain, hal ini pun didukung oleh hasil wawancara bahwa anggota yang beretnis Batak Toba bekerja keras dengan menyakini satu prinsip yaitu bekerja untuk mencapai kehormatan, dari hasil frekuensi 
yang menunjukan sekitar 17 orang memiliki nilai kerja kehormatan. Menurut anggota Brimob yang beretnis Batak Toba ketika individu sudah mendapatkan kehormatan dalam bekerja berarti kebutuhan akan uang sudah terpenuhi dan semua tujuan tersebut hanya untuk keluarga.

Falsafah dan tujuan hidup $3 \mathrm{H}$ tersebut Sudah tertanam dalam diri orang Batak Toba yang menyebabkan terjadinya sikap dan perilaku dalam bekerja untuk mencapai nilai hidup tersebut (Sitanggang, 1996). Nilai Hamoraon Hagabeon Hasangapon (3H) menjadi filosofi dan cita-cita masyarakat suku Batak Toba. Nilai $3 \mathrm{H}$ ini telah terinternalisasi di dalam diri setiap masyarakat suku Batak Toba sejak anak-anak. Walaupun demikian, $3 \mathrm{H}$ ini bukanlah hal yang mudah untuk diraih. $3 \mathrm{H}$ diraih dengan cara meraih ilmu setinggi-tingginya, bekerja keras sehingga dapat memenuhi kebutuhan hidup, menjadi teladan masyarakat, memiliki perilaku yang baik dan menunjukkan kepedulian kepada masyarakat sehingga dihormati di lingkungannya. Jika Nilai $3 \mathrm{H}$ ini telah diraih, maka dapat dikatakan cita-cita di dalam hidup mereka telah tercapai (Simarmarta, 2017).

Falsafah dan tujuan hidup etnis Batak Toba juga sejalan dengan aspek-aspek nilai kerja yang dikemukan oleh Wollack (dalam Sheilla, 2013) yang mengemukakan bahwa nilai ekstinsik individu terdiri dari attitude toward searning yaitu bahwa nilai kerja individu dalam bekerja akan memunculkan sikap untuk berusaha meningkatkan penghasilan atau menghasilkan uang sebnyaknya, hal ini senanda dengan konsep Hamoraon yaitu mencari dan mengumpulkan kekayaaan, selain itu juga terdapat aspek social status, yaitu nilai kerja seseorang juga digerkan oleh status sosial. Teori ini mendukung hasil penelitian dimana 19 orang memiliki nilai kerja kehormatan, dimana anggota Brimob etnis batak Toba memiliki keyakinan bekerja sebagai anggota Brimob merupakan suatu kebanggaan yang mengangkat satsus sosial meraka sehingga melalui pekerjaan tersebut mereka mendapatkan status sosial yang baik atau kehormatan. Berikut tabel hasil penelitian nilai kerja:

Tabel 2 Nilai Kerja

\begin{tabular}{clcc}
\hline No & Nilai kerja & Frekuensi & Persen \\
\hline $\mathbf{1}$ & Kehormatan & 17 & $37.8 \%$ \\
\hline $\mathbf{2}$ & Disiplin & 13 & $28.9 \%$ \\
\hline $\mathbf{3}$ & $\begin{array}{l}\text { Tanggung } \\
\text { Jawab }\end{array}$ & 9 & $20.0 \%$ \\
& Keluarga & 2 & $4.4 \%$ \\
\hline $\mathbf{4}$ & Kejujuran & 2 & $4.4 \%$ \\
\hline $\mathbf{5}$ & Kerja keras & 1 & $2.2 \%$ \\
$\mathbf{6}$ & Ikhlas & 1 & $2.2 \%$ \\
$\mathbf{7}$ & Jumlah & 45 & $100 \%$ \\
\hline
\end{tabular}

Dari tabel di atas ditemukan yang memiliki nilai kerja yang paling banyak dimiliki oleh anggota satuan Brimob yaitu kehormatan sebanyak 17 orang, disiplin sebanyak 13 orang, nilai tanggung jawab ada sebnayak 9 orang, nilai kejujuran dan keluarga ada masing-masing sebanyak 2 orang dan nilai ikhlas dan tanggung jawab masing-masing dimiliki oleh 1 orang.

Konsep 3H juga sesuai dengan teori yang diungkapkan oleh Tevruz dan Turgut (dalam Ucanok, 2008) nilai kerja memiliki aspek duniawi yaitu untuk mencapai kenikmatan atau status pencapain terhadap sesuatu yang diingikan dan dibutuhkan. Dikaitkan dalam work values Inventory konsep $3 \mathrm{H}$ akan seleras dengan aspek core value dari aspek status yaitu nilai kerja individu untuk mencapai kehormatan dalam status sosial dan merupakan bagian dari pencapaian yaitu memiliki keyakinan untuk mencapai tujuan, dimana tujuan etnis Batak Toba yaitu untuk mencapai hagabeon, hamoraon dan hasangapon $(3 \mathrm{H})$.

Pada penelitian Ramzy (2009) yang meneliti tentang "pengaruh nilai kerja terhadap kinerja lingkungan di bandara", menemukan 5 (lima) nilai kerja yang paling dominan dalam mempengaruhi kinerja lingkungan bandara antara lain adil, berpikir positif, bijaksana, cerdas, dan dedikasi/pengabdian.pada penelitian tersebut tidak melihat dari konteks budaya. Sedangkan dalam penelitian ini melihat dari konteks budaya, dimana nilai kerja anggota satuan Brimob yang memiliki skor tinggi yaitu kehormatan, kekayaan, 
keluarga disiplin, tanggung jawab, kejujuran, dan ikhlas. Nilai kerja tersebut merupakan perpaduan

\section{Kesimpulan}

Nilai kerja yang diyakini oleh satuan anggota brigade mobile kepolisian daerah Sumatera Utara yang ber-etnis Batak Toba adalah kehormatan, kekayaan, keluarga yang masih dominan dengan falsafah hidup Etnis Btak Toba yaitu 3H (hagabeon, hamoraon dan hasangapon).Falsafah $3 \mathrm{H}$ tersebut yang mengerakan dan memotivasi anggota untuk bekerja disiplin, tanggung jawab, kejujuran, kerja keras dan ikhlas. Dalam penelitian ini, nilai kerja memiliki hubungan yang positif dengan etnis Batak Toba.

\section{Kepustakaan}

Chu, K. H. A. (2007). A factorial validation of work value structure: Second-order confirmatory factor analysis and it is implications. USA: Tourism Management.

Jayanti, F. A., Yudi, S., Tri, M. (2015). Nilai kerja pada anggota TNI-AD berdasarkan tahapan karir. Psympathic, Jurnal Ilmiah Psikologi, 2(1), 79-93.

Morissan, M. A. (2012). Metode penelitian survei. Jakarta: Media Kencana

Sagala, Muller. (2014). Implementasi etos kerja dalam meningkatkan kinerja sekretaris. Jurnal ADB'S Secretary, 3(1), 12-19.

Sheilla. (2013). Studi indigeneous dinamika nilai kerja karyawan bersuku Jawa. Journal of Social and Industrial Psycholgy, 2(1), 112.

Sibarani, R. (2013). Folklor sebagai media dan sumber pendidikan: Sebuah ancangan kurikulum dalam pembentukan karakter siswa berbasis nilai budaya Batak Toba. Yogyakarta: Folklor Nusantara.

Simarmarta, P. I. N. (2017). Job performance ditinjau dari iklim organisasi dan nilai budaya suku Batak. JIPT, 05(01), 3542. antara budaya batak Toba dengan konsep 3H dan budaya organisasi Satuan Brimob.

Sinaga, R. (2000). Adat budaya Batak dan Kekristenan. Jakarta: Dian Utama

Sitanggang. (1996). Tradisi umpasa suku Batak Toba. Pusat pembinaan dan pengembangan bahasa departemen Pendidikan dan Kebudayaan. Jakarta

Sugiyono. (2014). Metode penelitian kombinasi (mixed methods). Alfabeta: Bandung.

Tambunan, K. (2015). Batak (Toba) society empowerment through creative economy based "dalihan na tolu" concept. Journal of Humanities and Social Science (IOSR- JHSS), 20(11), 77-83.

Walker. (1992). Patterns of polising: A comparative international analysis. Australia: New Brunswich. 